\title{
Kazakistan ve Türkiye’deki Ahşap Beşiklerin Tarihi Sanatsal Özellikleri
}

\author{
Gulbanu KOSHENOVA
}

Ahmet Yesevi Uluslararası Türk-Kazak Üniversitesi, Tarih-Pedagoji Fakültesi

\begin{abstract}
Özet
Beşik çeşitlerinde gelenek-görenek ve yaşam şartlarına göre değişikler görülmektedir. Genellikle halk arasında yaygın olarak bilinen ağaç veya metal iskelet üzerine yapılanların yanında özellikle yaylak-kışlak olarak yaşayan toplumların kullandığı el dokuması beşikler de bulunmaktadır. Çalışmamızda Kazakistan'da halen kullanımda olan ve Anadolu'da ise, eski dönemlerde kullanılmış ahşap beşiklerin yapım tekniğine ağırlık verilmiştir. Bunun yanı sıra beşiğin tarihi, biçimi ve türleri karşılaştırıldı. Anadolu bölgesi, daha çok orman varlığı ve ahşap süsleme işçiliği bakımından zengin sayılmaktadır. Orta Asya'da da beșikler genelde ağaçtan imal edilmiștir. Ağaç olarak çoğunlukla soğuğa dayanıklı ceviz kullanılmaktadır. Anadolu'da ise ağaç ve madeni beşiklerin yapıldığı bilinmektedir. Bununla birlikte Orta Asya ve Anadolu'da ahşap beşikler bölgede yetişen ağaçlardan üretilmiştir. Örneğin, kestane, kızılağaç, kayın, lâdin vb. ağacından da beşik yapılmaktadır. Söz konusu ağaçların üzerine yapılan oyma tekniği ve sanatsal işlemler asıl konumuzun özünü teşkil etmektedir. İnceleme sırasında Kazakistan ve Türkiye'deki beşiklerin (Fotoğrafli) görsel örneklerinin teknikleri üzerinde durularak, farklılıkları ile ortaklıkları tespit edilmek üzere kıyaslanarak ele alındı.

Anahtar Kelimeler: Orta Asya ve Anadolu, Beşik, Oyma tekniği, Süsleme, Ahşap Sanatı.
\end{abstract}

\section{Historical and Artistica Features Of Wood Cribs In Kazakhstan And Turkey}

\begin{abstract}
The kinds of cribs were differing from traditions and living conditions. Besides the widely-known wood or metal cribs, there were hand-made ones that belonged to nomads. Current study was focused on the making techniques of wood crib that are still using in Kazakhstan and it was used in ancient Anatolian. At the same time, the histories, forms and types of cribs were compared. The Anatolian area was considered to be rich in forests and wood trimming work in crib making. Cribs in Central Asia were usually made of wood. Walnut wood is used mostly in making cribs because it was cold-resistant. Anatolian was known as making wood and metal cribs. At the same time, wooden cribs in Central Asia and Anatolia were made from trees grown in the region. For example, cribs were also made from the trees like alder, beech, spruce and so on. The carving technique and decorating processes on the trees were essentials topics of this study. In observing process, the study focused on the techniques of visual samples of cribs (pictures) in Kazakhstan and Turkey, their differences and similarities were compared and contrasted.

Key Words: Central Asia and Anatolia, cribs, Carving, Decorating, Wood Art.
\end{abstract}

\section{Giriș}

Anne açısından pratik, kullanışlı ve rahat, çocuk açısından ise hem fizik hem de psikolojik bakımdan daha sağlam, dinlenme yeri olarak huzurlu olan beşik, çok eskiden beri çoğu Türk ailesinde kullanılmaktadır. Çocuk kendini ayakta tutabilecek hâle gelene kadar yaşayacağı yeri ve küçük evidir. Çocuğun büyümesinde birçok açıdan faydalı olmaktadır. Beşiğin Türklerde çok eski tarihlerden beri kullanıldı $\breve{1}$ bilinmektedir. Orta Asya'da yapılan kazılarda M.Ö. I. yüzy1la ait Hun gömüdünde bulunan malzemeler arasında ahşap beşik de vardır. Bulunan bu beşik günümüzde Kazak ve Kırgız Türklerinin kullandıkları beşiklere benzemektedir. Başkurtların kayın ağacından oyma tekne gibi beşikler kullandıkları bilinmektedir. Türk dünyasının her yöresinde çeşitli tarihlerden kalma beşiklere rastlanmıştır.

Beşik, anne ve çocuk için faydalı olmanın yanı sıra, bu özellikleriyle geçmişte göçebe hayatı yaşayan bütün Türk toplulukları için kolaylık sağlamıştır. Sade, kullanışlı ve taşınması kolay olan beşik bugüne kadar da varlığını sürdürmüştür. Dolayısıyla beşik tarihinin çok eskilere dayandığı bellidir. Bu konuda çalışmamda kaynak eksikliği acısından halk bilimiyle ilgili bilgilere dayanarak ele alındı. Beşikleri incelerken sadece genel olarak değerlendirilmiştir. Günümüzde Kazakistan'ın Güney bölgesi çerçevesinde kullanılmakta olan beşiklerle Anadolu'nun Karadeniz yöresine ait olan beşiklerle mukayese ederek, farklılıkları ve ortak özellikleri hakkında değerlendirmeye çalışmıştır.

\section{Beşik terimi ve beșiğin genel anlamı}

Beşik, Türkçe bir kelime olup: "Süt çocuklarını yatırmaya ve sallayarak uyutmaya yarayan, tahta ve demirden yapılmış sallanır bir çeşit küçük karyola" anlamına gelmektedir. Kelime, Eski Türkçeden beri kullanılmaktadır. Mecazi olarak da: "Bir şeyin doğup geliştiği yer." manasında kullanılmaktadır. beşi- (sallamak) fiil kökü ve $+k$ fiilden isim yapma eki ile yapılmış isimdir. Bulgarcaya besik, Sırpçaya besika biçiminde geçmiştir (Eren 1999: 48).

Divanü Lügati't-Türk’te Beşik kelimesi çocuk beşiği anlamında geçmekte ve beşik sallamakla ilgili pek çok fiil kullanılmıştır. Eski Kıpçak Türkçesinde de beşik kelimesi kullanılmaktadır. Günümüz Türk lehçe ve şivelerinin tamamında beşik kelimesi ya da beşik kelimesinin ses değişmesine uğramış biçimleri (bişik, besik ${ }^{1}$, pejik vb.) karşımıza çıkmaktadır (Atalay 1986: 86).

Beşik yapan ustaya ve satan kişiye beşikçi denir. Beşik ana kucağından sonraki yuvadır. Hayata başlangıçtır.

\footnotetext{
${ }^{1}$ Kazakça sözcük.
} 
Buradan başlayan hayat, mezara kadar sürüp gider. O yüzden insan ömrü anlatılırken "beşikten mezara kadar" denilir. Çok eskiden beri tanıdığını anlatmak için "beşiğini sallamak" deyimi kullanılmaktadır.

Beşik kelimesiyle başka deyimler ve birleşik kelimeler de yapılmıştır. Orta Asya ve Anadolu'nun beşikle ilgili örfadetleri bulunmaktadır. Orta Asya'da yeni doğan çocuğa beşik töreni düzenlenecektir. Bu törende en mühim misafirler çocuğun annesinin ailesidir (dayı tarafı). Çünkü merasimde en başta beşik olmak üzere çocuk için gerekli eşya, giyimlerini, oyuncaklarına kadar bu törene getirecektir.

Kazak ailesinde beșiğin rolü mühimdir. Tüm ailede rastlanan beşikler, ustalar tarafından ağaç oyma işçiliğiyle yapılmıştır. İnanç gereği kendi çocuğuna ait beşiğe diğer ailenin bebeğini yatırılmamıştır. Eğer bebeği vefat ederse beşiği çocuğun mezarının başına koymuşlar (Bekeşov 2002: 76)

Kazakistan'da "Beşik dünür” (Kazakça: Beşik kuda), Anadolu'da ise "Beşik kertiği": "Daha beşikte iken anası babası tarafından nişanlanmış kimse"; Beşik kertme: "Daha beşikte iken anası babası tarafindan nişanlama”. Orta Asya Türkleri'nde "beşik kuda", "kadın kursak kuda" adıyla bilinen "beşik kertmesi" âdeti (Köse 2001: 31) Anadolu'da eskiden beşik kertme, iki aile arasındaki bağların ve dostluğun pekiştirilmesi veya mirasın bölünmemesi için anneler ve babalar arasındaki sözleşmedir. Beşik kertmeye karar verildiğinde aileler arasında, imamın da katıldığı, bir tören düzenlenir, dualar okunur, şerbetleri içilir. Çocuklar büyüyene kadar aileler arasında özel günlerde hediyeleşme olmaktadır.

Beşiklik: "Beşik yapılmaya, beşik yapımında kullanılmaya uygun"; Beşiklik etmek: "Beşik vazifesini, bir şeyin doğup gelişmesine yardımcı olmak”; Beşik salıncak: "Bayram yerinde kullanılan bir tür salıncak" (Eren 1999: 48).

Beşikörtüiü veya Beşik çatı: "Íki yana akıntısı olan çatı", Beşik tonoz: "Enine kesiti yarım çember şeklinde olan tonoz", Beşik kemer: "Yarım çember şeklinde kemer veya daire kemer" (Hasol 2010: 78).

Beşik kelimesinin gerek mecazi anlamı, gerekse kelime anlamı göz önüne alındığında; çocukların büyütülmesinde kullanılan, hafif, pratik ve basit araçlar halk dilinde beşik olarak anılmakta ve günümüzde kullanımı geleneksel veya modern biçimleri ile devam etmektedir.

Geleneksel yaşam içerisinde beşiğin Türklerde çok eski tarihlerden beri kullanıldığı bilinmektedir. Orta Asya'da yapılan kazılarda M.Ö. 1. Yüzyıla ait bir Hun gömütünde bulunan malzemeler arasında bulunan ahşap parçalar beşik kalıntıları olarak değerlendirilmiştir.

Hunlara ait çeşitli bölgelerdeki kazılarda gün 1şı̆̆ına çıkarılmış ahşap eserler de görülen eğri kesim ve oyma teknikleriyle yapılmış hayvan heykelcikleri ve at koşum takımları bulunmuştur (Çoruhlu 2007: 142). Dolaysıyla, Orta Asya'da yaşayan Türklerin Ahşap süsleme sanatının ileri gitmiş olduğu anlaşılmaktadır.

Genellikle beşik kullanımındaki asıl amaç, çocuğu dış etkilerden korumak, uyumasını hızlandırmak. Üzerine örtülen örtüler ile 1şığı kırmak ve beşiğin sallanmasını sağlayarak çocuğun rahatlamasına yardımcı olmaktır (Fotoğraf 1-2). Beşik çeşitlerinde gelenek-görenek ve yaşam şartlarına göre değişikler görülmektedir. Genellikle halk arasında yaygın olarak bilinen ağaç veya metal iskelet beşikler kullanılmıştır. Beşiğin bütün malzemeleri yuvarlak veya ovaldir.
Hiçbir parçasının kesici veya delici özelliği yoktur. İnsan vücudunu herhangi bir biçimde yaralayacak parçası bulunmamaktadır.

Çocuk, beşiğe yörek (jörgek ${ }^{2}$ ) denilen bir kumaşla sarılmaktadır. Bu kumaş çok geniş olup çocuğu iyice kavramaktadır. Beşik devrilse bile çocuğa zarar gelmesi mümkün değildir.

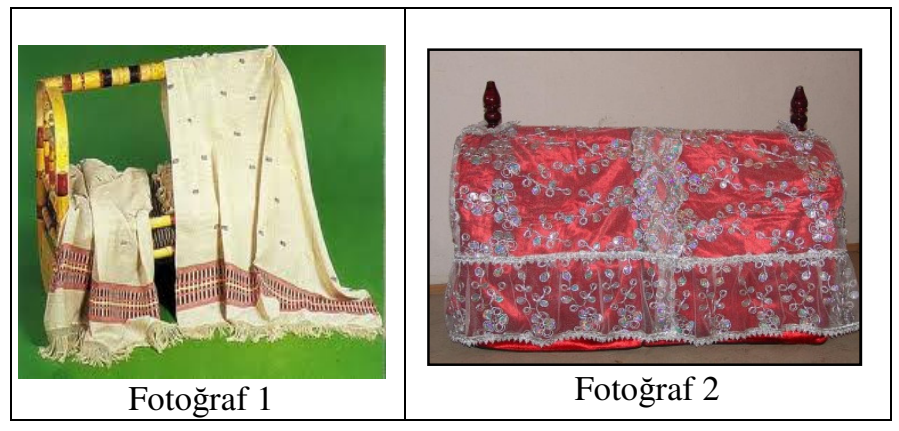

\section{Orta Asya'da Genel Olarak Beşiğin Biçimi ve Ahşap Beşiklerinin Yapımı}

Beşik, az ve çok farklılıklarla dünyanın her bölgesinde kullanılmaktadır. Asıl amaç çocuğun sallanması, sallanarak rahat yatması ve rahat uyuması olduğu için yapı bakımından genellikle birbirilerine benzerler. Genellikle sallanmayı sağlayan iki kasnak, iki kasnağı birbirine bağlayan kollar, tekne biçiminde bir yataktan ve yatak yerinden oluşmaktadır.

Türklerin ata yurdu olan Orta Asya kurganlardan ele geçirilen ağaç işçiliğiyle yapılmış malzemeler Türk Halklarının eski devirlerden itibaren ağaç işçiliğiyle uğraştığını göstermektedir. Beşik işçiliğinde de çeşitli ahşap teknikleri uygulanmış örneklere rastlanır. Orta Asya'da(Kazakistan, Özbekistan) beşikler yapımında genelde yuvarlak satıhlı oyma ve boyama tekniklerini tercih ettiğini görmekteyiz.

Ahşaplarda ahşap zeminin oyulması suretiyle motiflerin kabartma olarak ortaya çıkarıldığı oyma tekniğinin ve üzerine boyayarak iki tekniğin bir arada kullanılmış örnekler yaygındır (Öney 1970: 147), (Fotoğraf 3-4-5).

Beşik yapımında genelde kırmızı renginin tonları, sarı, mavi renginin tonları, bordo, siyah, siyah, kahverengi, altın yaldızlı renkleri ve pembe renkleri boyama tekniğinde kullanılmaktadır.

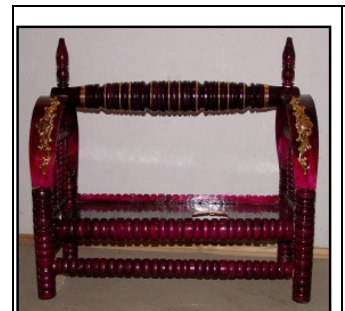

Fotoğraf 5

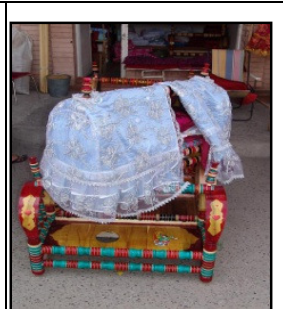

Fotoğraf 3

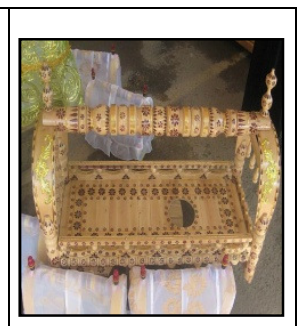

Fotoğraf 4
Beşik, meyveli ağacın yanı sıra dut ve söğüt ağacından yapılır. Dört ayaklı, düz tahta, yatak ve lazımlık (tuvakı, tübek ${ }^{3}$ ) (bebeğin tuvaletinin düştüğü bir tür beşik

\footnotetext{
2 Kazakça sözcük

${ }^{3}$ Kazakça sözcük
} 
aleti) tutması için yapılan özel delikten ibarettir (Fotoğraf 67-8). İki yanı ve ayak taraflarının üst kısmı yay şeklindedir ve üzerinde bir yuvarlak destek ile bir birine bağlanmıştır. Ayrıca iki ucunda sallamak için kolları bulunmaktadır (Fotoğraf 6-7-8).

\section{Lazımlıklı (Tuvaklı) beșikler;}

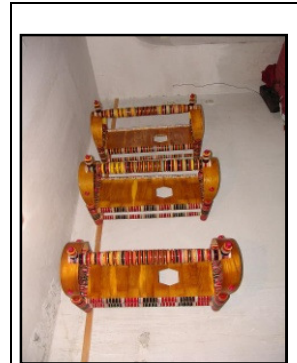

Fotoğraf 6

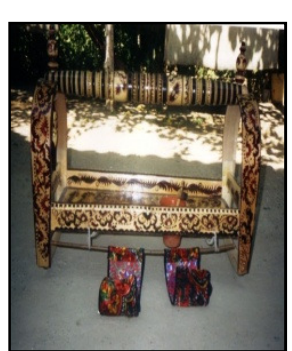

Fotoğraf 7

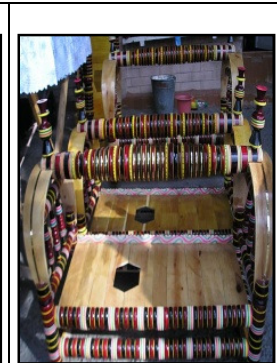

Fotoğraf 8
Alt kısmın kaymaması ve çalkalanmaması için daha ağır olan dut ağacından; iki ayağın üst tarafındaki yay kısmı ve kalın direkler, sallamak için kolları, yukarı taraftan kolay ve hafif sallamayı sağlayan ara destek sögüt ağacından yapılır. Üzeri yazın ince tül, kışın ise kalın kadife kılıflarla örtülür. Bebeğin, oğlan veya kız olmasına göre iki çeşit sumak (bebeğin ön tuvaletinin beşiğe düşmesini sağlayan, ağaçtan yapılmış bir tür beşik âleti) kullanılır (Fotoğraf 9-1011 ). Şümek, koyun ve keçinin aşık kemiğinden yapılmış alettir. Kemiğin aşık bulunan başını kapalı şekilde bırakılarak çıkıntıları törpülenir. Sonra kemiğin kalın olan ikinci ucu bıçakla keserek, çıkıntılarını törpüledikten sonra yağda kaynatarak kullanılmıştır (Şokparulı 2007: 77).

\section{Beşik aleti;}

Erkek çocuk sumağı (Fotoğraf 9). Kız çocuğu sumağ1 (Fotoğraf 11).

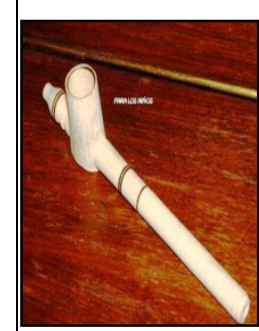

Fotoğraf 9

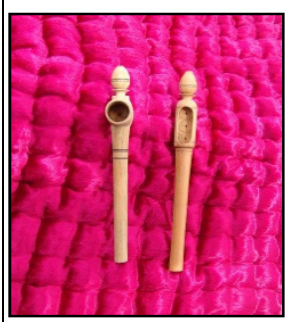

Fotoğraf 10

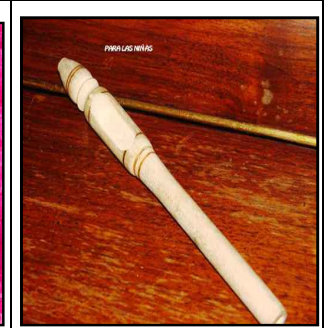

Fotoğraf 11
Beşik, birçok yere, hatta avlu veya tarlada taşınabilir özelliğe sahiptir. $\mathrm{Bu}$, anne için kolaylık sağlamakta, yeri geldiğinde çocuğa bakmanın yanı sıra, başka işleriyle de ilgilenebilmesine imkân yaratmaktadır. Beşiğin biçimi öyle yapılmıştır ki, bebeği sallamak, avutmak, sevmek, ninni söylemek, uyutmak için çok müsaittir.

Çeşitli örtülerle kısmen veya tamamen kapatılması, çocuğu kışın soğuktan, yazın ise sıcaktan, güneşten, rüzgârdan, gürülttüden korumuştur. $\mathrm{Bu}$ örtü çocuğu dış etkenlerden koruması, özellikle çocuk uyurken dikkati dağıtacak olaylardan uzak tutması bakımından faydalıdır.

Çocuk beşiğe (özel kol- ayak bağı ile) bağlanır. Bu ilk bakışta sanki çocuğa işkence yapılıyormuş gibi görülse de, bağlar çocuğa fazla hareket yapmadan, kendi kol ve ayakları yüzünden ani korku yaşamadan, hiç bir şeye çarpmadan, yattığı yerde yanlış bir şekilde dönmeden, rahat ve sakin uymasına imkân yaratır (Fotoğraf 12-13).

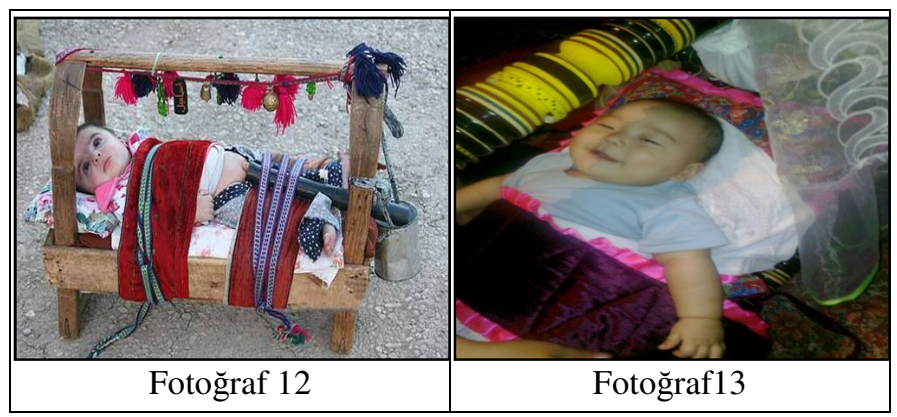

Beşikte çocuğun ayakları arasına sumak, altına tuvak yerleştirilmesi nedeniyle çocuğun altı nemlenmez, sırtında pişik oluşmaz, aynı zamanda bunlar üşümemesini sağlar (Fotoğraf 14-15-16).

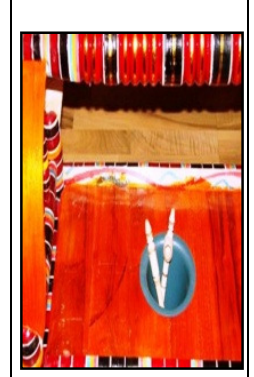

Fotoğraf 14

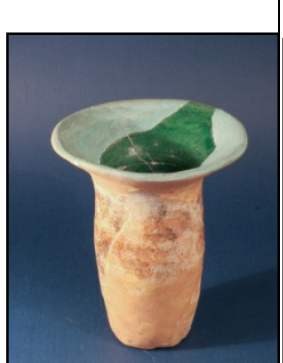

Fotoğraf $15^{4}$

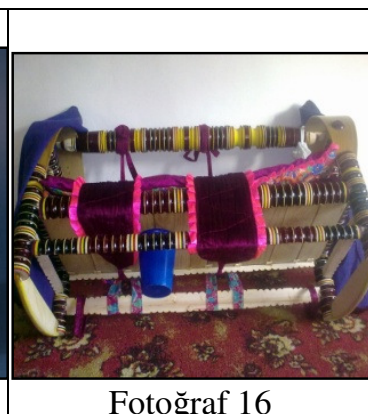

Fotoğraf 16

\section{Anadolu Beşiklerinin Yapılışı}

Beşik işlemesi kolay ve dayanıklı ağaçlar tercih edilmekle birlikte, daha çok abanoz, ceviz, servi, kestane, kızılağaç, kayın vb. ağaçlarından yapılmaktadır.

Anadolu'da varlıklı aileler genelde ceviz ağacından muhteşem oyma tekniğinde yapılmış beşikler kullandıkları biliniyor.

Anadolu beşiklerinin ihtiyaç boşaltım yapım sistemi Orta Asya'daki (Kazakistan) beşiklerinden farklıdır. Erkek (Fotoğraf 17, sağdaki) ve k1z çocuğunun teneke ördekleri (Fotoğraf 17-18 ${ }^{5}$.

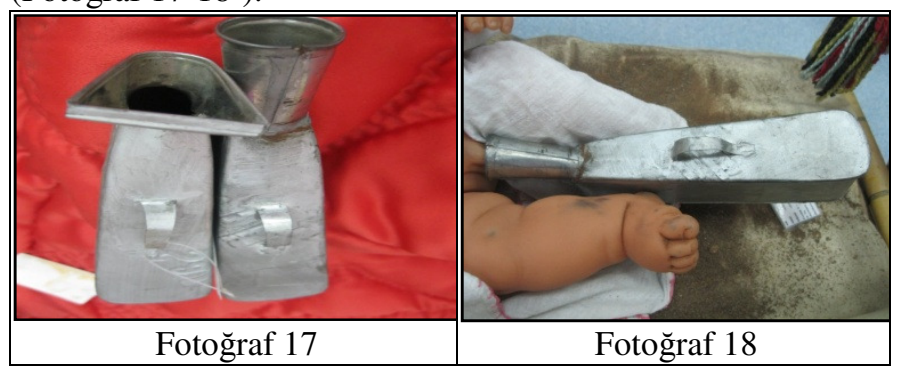

Anadolu'da (Çorum yöresi) beşiğin baş tarafına sarı renkli türben takma örf âdeti vardır (Fotoğraf 19-20). Halkın inancına göre, çocuğu sarı hastalıktan korurmuş.

\footnotetext{
4 Kazakistan, Almatı şehri Merkez Müze arşivindeki lazımlık olarak değerlendirilmiş içi sırlı seramik.

5 Gazi Üniversitesi, Somut Olmayan Kültür Miras Müzesi arşivinden çekilmiş erkek ve kız çocuklarının beşik ördekleri fotoğrafı.
} 
Çorum bölgesinden getirilmiş beșik ${ }^{6}$.

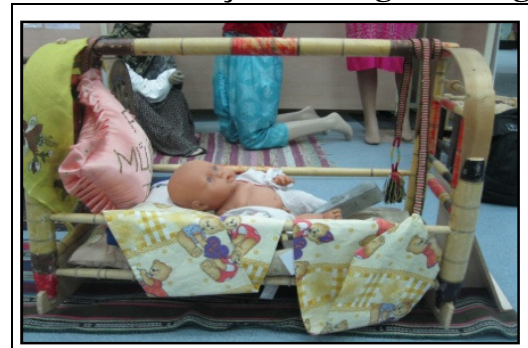

Fotoğraf 19

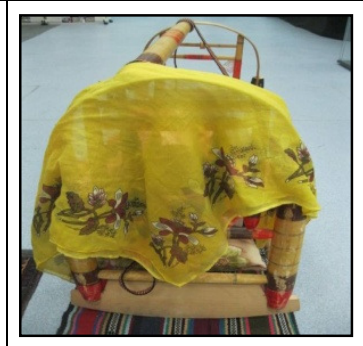

Fotoğraf 20
Anadolu'da Selçuklularla gelişen ve orijinal bir üslup yaratan ahşap işçiliği büyük ustalıkla işlenmiş birçok eser ortaya koymuştur. Özellikle ceviz, elma, armut, sedir ağacından yapılarak ahşap malzemede çeşitli teknikler uygulanmıştır. Anadolu Selçuklularının daha çok oyma (kabartma), kündekâri (çatma, geçme), boyama tekniklerini kullandıkları görülür. Yaygın olarak kullanılan oyma tekniğinde motifler, ağaç yüzeyi oyularak kabartma halinde ortaya çıkarılmıştır. Oyma tekniğinin işleniş biçimlerine göre; düz satıhlı derin oyma, yuvarlak satıhlı derin oyma, çift katlı kabartma oyma gibi şekilleri vardır. Ahşap sanatında en çok kullanılan tekniklerden biri olan, motiflerin arasının oyularak desenin ortaya çıkartıldığı oyma ya da kabartma tekniğinde; işlenen motiflerin yüzeyi düz bırakılırsa buna düz satıhlı (yüzeyli) oyma, yuvarlatılırsa yuvarlak satıhlı (yüzeyli) oyma denir (Öney 1970: 141) Ceviz ağacından kasnak altı ve iki yan kısmı bitkisel motif uygulanarak yuvarlak satıhlı (kabartma) oyma işçiliğinde yapılmış beşik örneğini görmekteyiz (Fotoğraf 21 )

Anadolu Selçuklu ahşap işçiliğinde rastlanan kafes tekniği özellikle minber ve mahfil yapımında, minberlerin korkuluk kısımlarında kullanılan bir tekniktir Ahşap kirişlerin geometrik motifler (çokgen, üçgen, yıldız) oluşturacak şekilde bir araya gelerek çakılması sonucunda elde edilir (Öney 1992: 121). Beşiklerin de iki yan kısmında da bu kafes tekniğinin uygulanmış örneklerini görmekteyiz (Fotoğraf 22). Devirlere göre tercihler değişmekle birlikte, oyma, kakma ve kafes gibi diğer ahşap teknikleriyle birlikte kullanılmıştır (Bozer 2002: 913).

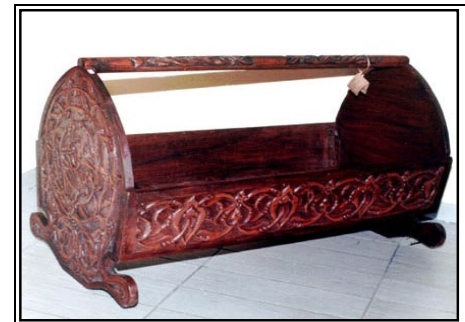

Fotoğraf 21

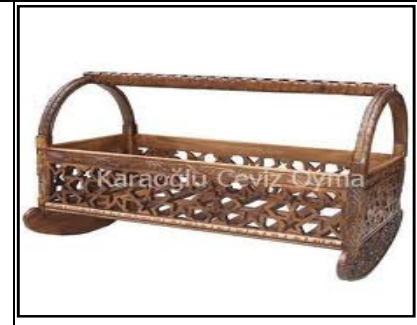

Fotoğraf 22
Kastamonu yöresinden getirilen ahşap motiflerin yüzeylerinin aralarının oyulup çıkartılmasıyla gerçekleştirilen ajur tekniğiyle yapılmış beşik örnekleri (Fotoğraf 23-24 $4^{7}$ ).

\footnotetext{
${ }^{6}$ Gazi Üniversitesi, Somut Olmayan Kültür Miras Müzesi arşivinden.

${ }^{7}$ Gazi Üniversitesi, Somut Olmayan Kültür Miras Müzesi arşivinden.
}

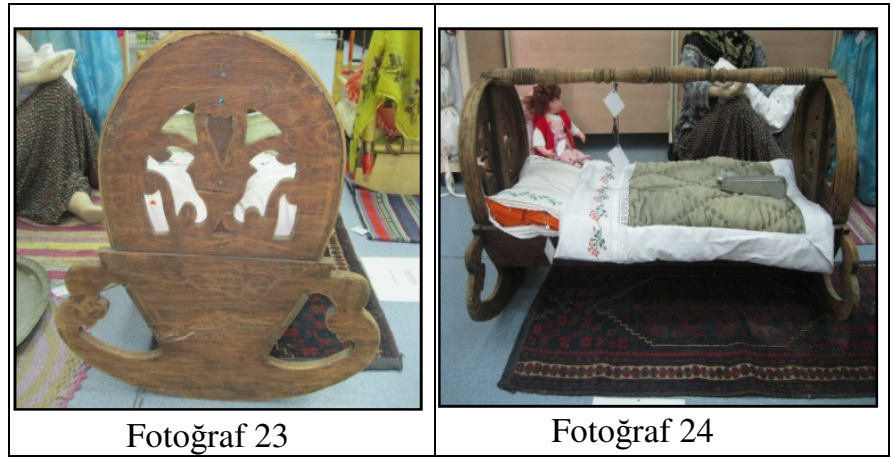

Urfa'da ajur tekniğiyle yapılmış kasnak altında kalp motifli ve bitkisel süsleme içerisinde kıvrım dallar ve yapraklarla işlenmiş beşik (Fotoğraf 25-26-27).

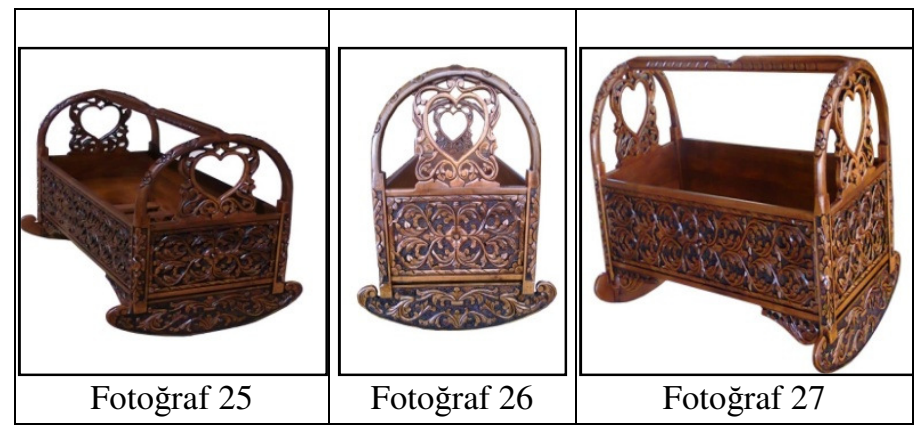

Farklı renklerde boyanmış daha çok Orta Asya beşiklerine benzeyen beşikler (Fotoğraf 28-29-30).

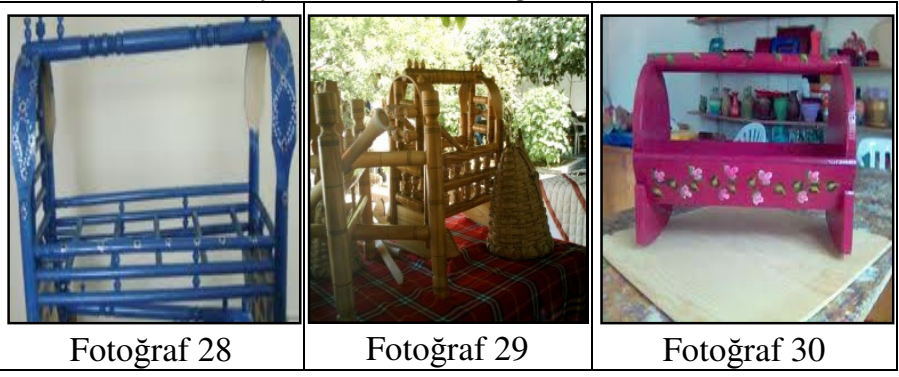

XV. yüzyıldan itibaren madenî beşikler de görülmeye başlamıştır. Altın, gümüş ve bronz beşikler de tarih içinde kullanılmıştır. Maden işçiliğine örnek olarak gösterilen Fotoğrafde tuvak deliği yer almaktadır. Bu tek ve farklı örneğimizdir (Fotoğraf 31).

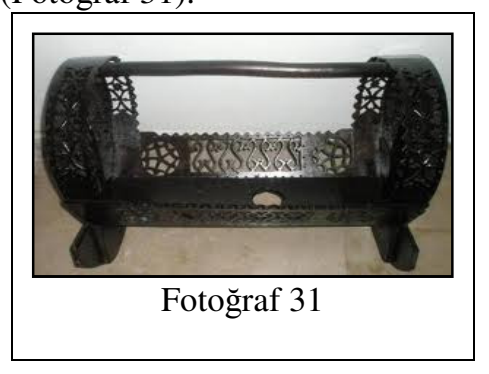

Osmanlı Dönemi'nde özellikle sarayda kullanılan beşikler değerli madenlerden ve ağaçlardan yapılmıştır. Bunlardan en ünlüsü Topkapı sarayında sergilenen Altın Beşiktir.

Oyularak boşaltılan alana farklı renk, ya da farklı malzemelerin boşa alana uygun olarak hazırlanan parçaların yerleştirmesiyle oluşan kakma tekniği uygulanmış olan Altın 
beşik İncili örtüsü ve mücevherlerle süslü altın bağırdakları on altıncı asır Türk kakmacılık ve kuyumculuk sanatının şaheserleri arasındadır. Paha biçilememektedir. Örtüsü kül rengi dibadan yapılmış, üzerine inci ve zümrüt işlenerek oturtulmuştur. Beşiğin oya gibi işlenmiş altın yaftaları üzerinde 1475 parça elmas, 1210 parça yakut, 520 parçada zümrüt vardır. İki yan tahtalarındaki zümrüt ve elmaslar çok büyük ve temizdir.

Beşiğin topuzları ve sapı da tamamen mücevheratla örtülmüştür. Yalnız iki topuzunda sekizer elmas, beşer yakut ve on beşer zümrüt vardır. Örtünün üzerindeki incilerin tahmini sayısı 10 milyon kadardır. Beşiğin sekiz bağırdağı ile bağırdak çubuğunda 140 elmas 132 yakut 842 zümrüt vardır. Kakma tekniğiyle yapılmış Altın beşik birçok şehzadenin beşiği olmuştur (Fotoğraf 32-33).

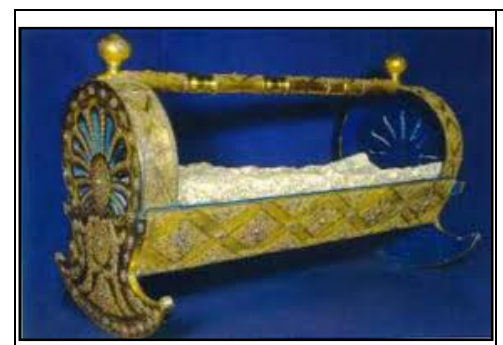

Fotoğraf 34

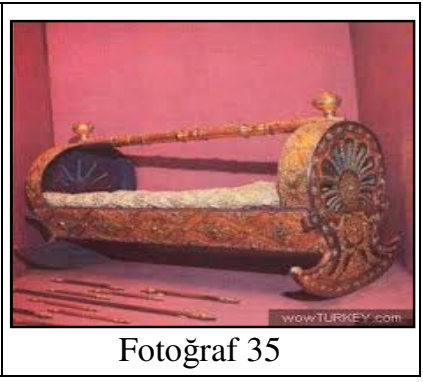

\section{Sonuç}

Çalışmamızda genel olarak Orta Asya ve Anadolu beşiklerinin yapım tekniklerine değinildi. El sanatlarının biri olan beşik yapım sanatını bir bütün olarak ele alırsak, sayısız örneklerle benzer ortaklıklar bulunacağı doğaldır. Çalışmamızda beşik ahşap işçiliğini konu olarak seçip, benzerlikleri mukayese etmeye çabalandık. İlginç ve sırlarla dolu konumuzun daha nice ilmi araştırmalara başlık olacağı açıktır. Kaynak ve beşik örneklerinin eksikliğinden dolayı bu konu ayrıntılı araştırılmamıştır.

Türklerin Ata yurdu olan Orta Asya'dan temelini alarak, Anadolu'da gelişerek beşik sanatı devam etmiştir. Beşikler bir birine benzerlik gösterse de bazı süsleme açısından farklılıklar gösterir. Beşiklerde görülen farklılıklar coğrafya ve yaşam biçiminden kaynaklanmaktadır. Beşik, anne ve çocuk için faydalı olmanın yanı sıra, bu özellikleriyle geçmişte göçebe hayatı yaşayan bütün Türk toplulukları için kolaylık sağlamıştır. Sade ve kullanışı olarak bugüne kadar da varlığını sürdürmüştür.

Beşiğin en önemli özelliği, bebek ve çocuklar için son derece güvenli olmasıdır. Hangi şartta olursa olsun, çocuğa zarar vermeyecek bir yapıda ve çocuğu yaralamayacak bir biçimde yapılmaktadır. Orta Asya beşikleri, genelde süslemesiz renkli boyalarla yapıldığını örneklerden anlaşılmaktadır. Kazakistan bölgesinin genelinde, özellikle Güney Kazakistan bölgesinde beşik kullanımı hâlen devam etmektedir.

Anadolu'da ise, geçmiş dönemlerde beşiklerin muhteşem ahşap teknikleri uygulanarak işlenmiş beşik çeşitlerinin kullanıldığını söyleyebiliriz. Beşiklerin süslemesi bölgeye göre değişiklik arz etmiştir. Türkiye'de hızlı sanayileşme nedeniyle geleneksel malzemelerin (beşiklerin) yerini sanayi (modern bebek beşikleri) ürünlerinin almıştır. Günümüzde beşik ve beşikçilik el sanatları sona ermek üzere olan araç ve zanaatlar içerisine girmiştir. Bununla birlikte çağımızda çocuklar elde taşındığı için beşik pek kullanılmaz.
Onun yerine hafif, pratik ve basit araçlarla ihtiyaç karşılanılmaktadır.

\section{Kaynaklar}

Atalay, Besim (1986), Divanü Lûgat-it-Türk Dizini, İndeks,TDK Yay., Ankara.

Bekeşov, Sarsenğali (2002), Kazaktın dastürli ă̆aş oyu öneri, Yayınlanmamış Doktora Tezi, 140 sayfa, Almat1.

Bozer, Rüstem (2002), Ortaçağ Anadolu Türk Ahşap Sanatında Kündekari Tekniği, Türkler, Cilt 7, s. 911 916, Yeni Türkiye Yay. Ankara.

Çoruhlu, Yaşar (2007), Erken Devir Türk Sanatı, Kabalcı Yay., İstanbul.

Demir, Necati (2002), Karadeniz Bölgesi’nde Beşik / Beşik yapımı, (Makale) www.necatidemir.net, Alıntı tarihi: 25.04.2013.

Eren, Hasan (1999), Türk Dilinin Etimolojik Sözlüğ̈̈, Bizim Büro Basım Evi, Ankara.

Hasol, Doğan (2010), Ansiklopedik Mimarlık Sözlüğü, Yem Yay., İstanbul.

Köse, Nerin (2001), Kazakların Gelenek - Görenekleri ile Inanç ve Pratikleri. Milli Folklor Yay.,nu: 14, Folklor Dizisi: 4, Ankara

Öney, Gönül (1970), Anadolu Selçuklu ve Beylikler Devri Ahşap Teknikleri, Sanat Tar. Yıllığı III., İstanbul.

Öney, Gönül (1992), Anadolu Selçuklu Mimari Süslemesi ve El Sanatları, Türkiye İş Bankası Kültür Yay., Ankara.

Şokparulı, Darkembay (2007), Kazaktıñ Koldanbalı Öneri, Almatıkitap Yay., Almatı. 